\title{
Localized Genetic and Phenotypic Diversity of Xanthomonas translucens Associated With Bacterial Leaf Streak on Wheat and Barley in Minnesota
}

\author{
Rebecca D. Curland, ${ }^{1}$ Liangliang Gao, ${ }^{2}$ Cory D. Hirsch, ${ }^{1}$ and Carol A. Ishimaru ${ }^{1, \dagger}$ \\ ${ }^{1}$ Department of Plant Pathology, University of Minnesota, St. Paul, MN 55108 \\ ${ }^{2}$ Department of Plant Pathology, Kansas State University, Manhattan, KS 66506 \\ Accepted for publication 23 August 2019.
}

\begin{abstract}
Bacterial leaf streak (BLS) of wheat and barley has been a disease of increasing concern in the Upper Midwest over the past decade. In this study, intra- and interfield genetic and pathogenic diversity of bacteria causing BLS in Minnesota was evaluated. In 2015, 89 strains were isolated from 100 leaf samples collected from two wheat and two barley fields naturally infected with BLS. Virulence assays and multilocus sequence alignments of four housekeeping genes supported pathovar identifications. All wheat strains were pathogenic on wheat and barley and belonged to the same lineage as the Xanthomonas translucens pv. undulosa-type strain. All barley strains were pathogenic on barley but not on wheat. Three lineages of barley strains were detected. The frequency and number of sequence types of each pathovar varied within and between fields. A significant population variance was detected between populations of $X$. translucens $\mathrm{pv}$.
\end{abstract}

ABSTRACT undulosa collected from different wheat fields. Population stratification of $X$. translucens pv. translucens was not detected. Significant differences in virulence were detected among three dominant sequence types of $X$. translucens pv. undulosa but not those of $X$. translucens pv. translucens. Field trials with wheat and barley plants inoculated with strains of known sequence type and virulence did not detect significant race structures within either pathovar. Knowledge of virulence, sequence types, and population structures of $X$. translucens on wheat and barley can support studies on plant-bacterial interactions and breeding for BLS disease resistance.

Keywords: bacteriology, bacterial populations, ecology and epidemiology, multilocus sequence alignment, multilocus sequence typing, population biology
Bacterial leaf streak (BLS) is an internationally distributed disease that has become highly prevalent in wheat and barley production in the Upper Midwest and Northern Great Plains of North America (Adhikari et al. 2011; Curland et al. 2018; Kandel et al. 2012). BLS and black chaff, which results from infections of the spike, can cause significant yield losses (Duveiller et al. 1997; Tillman et al. 1999). BLS on cereal crops is caused by four pathovars of Xanthomonas translucens (Duveiller et al. 1997; Young et al. 2008). Pathovar designations, which are determined by host specificity, have been generally well supported by phylogenies predicted by multilocus sequence analysis (MLSA), repetitive element sequence based-polymerase chain reaction (rep-PCR), and single-nucleotide polymorphism analyses of draft and wholegenome sequences (Curland et al. 2018; Langlois et al. 2017; Young et al. 2008). The most common BLS pathovars affecting small grains production in the Upper Midwest are $X$. translucens pv. translucens and X. translucens pv. undulosa (Adhikari et al. 2012a, b; Curland et al. 2018). Host ranges of $X$. translucens pathovars are narrow and mainly restricted to members of the Poaceae. $X$. translucens pv. translucens (Jones et al. 1917) infects barley (Bragard et al. 1995; Smith et al. 1919; Vauterin et al. 1995), whereas $X$. translucens pv. undulosa (Smith et al. 1919) causes symptoms on barley as well as wheat, rye, and triticale (Bragard et al. 1995; Smith et al. 1919; Vauterin et al. 1995). The host ranges of X. translucens pv. cerealis (Hagborg 1942; Vauterin et al. 1995)

†Corresponding author: C. A. Ishimaru; cishimar@umn.edu

Funding: Funding for this project was provided by the Minnesota Wheat Research and Promotion Council and the Minnesota Small Grains Initiative.

*The $\boldsymbol{e}$-Xtra logo stands for "electronic extra" and indicates that one supplementary figure is published online.

The author(s) declare no conflict of interest.

(c) 2020 The American Phytopathological Society and $X$. translucens pv. secalis overlap with that of $X$. translucens $\mathrm{pv}$. undulosa (Reddy et al. 1924; Vauterin et al. 1995). In addition, $X$. translucens pv. undulosa has been shown to cause disease on ornamental asparagus (Rademaker et al. 2006) and wild rice (Bowden and Percich 1983).

Recommended management strategies for BLS in wheat and barley include crop rotation, planting disease-free seed, and using resistant varieties (Duveiller et al. 1997; Forster and Schaad 1988; Kandel et al. 2012). Treatments to reduce pathogen populations on or in seeds are ineffective, because under favorable environmental conditions, low bacterial populations can cause significant levels of disease (Duveiller et al. 2005). Management through genetic resistance to BLS is considered the better option. Considerable effort has been made to identify sources of resistance in national and international plant germplasm collections (Adhikari et al. 2012a, b; Duveiller et al. 1992; Kandel et al. 2012, 2015; Sapkota et al. 2018). Partial resistance that is quantitatively inherited and influenced by environmental conditions and host phenology has been identified in winter and spring wheat and barley (Adhikari et al. 2012 a, b; Alizadeh et al. 1994; Kandel et al. 2012; Tillman and Harrison 1996; Tillman et al. 1996). Although immunity to BLS has not been identified, high-level resistance has been identified in triticale (Cunfer and Scolari 1982; Sapkota et al. 2018). A major dominant gene $(X c t 1)$ conferring BLS resistance in triticale was located on $5 \mathrm{R}$ by genetic mapping of segregating populations from crosses with the resistant accession Siskiyou (Cunfer and Scolari 1982; Sapkota et al. 2018; Wen et al. 2018).

Genetic and phenotypic diversity is prevalent within regional and global collections of $X$. translucens isolated from wheat and barley (Alizadeh et al. 1997; Bragard et al. 1995, 1997; Duveiller et al. 1992; Maraite et al. 2007). Multilocus sequence typing (MLST) and MLSA of a large collection of isolates from Minnesota, North Dakota, and South Dakota found that strains from the Upper Midwest region are distributed across three clades of $X$. translucens pv. translucens and one clade of $X$. translucens pv. undulosa. Each clade contains multiple sequence types (STs) (Curland et al. 2018). 
Strains from the Upper Midwest also vary with respect to relative virulence (Curland et al. 2018). Evidence for genetic and phenotypic diversity has also been shown within a collection of North Dakota isolates of $X$. translucens pv. undulosa (Adhikari et al. 2012a, b) and in global collections of $X$. translucens strains from the Poaceae (Bragard et al. 1995; Curland et al. 2018; Hersemann et al. 2017; Langlois et al. 2017). Genetic and phenotypic diversity within and between populations of $X$. translucens pv. undulosa representing different production regions at the city scale has also been reported (Adhikari et al. 2012a, b). Diversity at smaller spatial scales, such as within infected fields, has not been evaluated thoroughly.

The importance of genotypic and phenotypic diversity in the pathogen on the effectiveness of disease-resistant cultivars for managing BLS is not clear. Unlike other Xanthomonas-plant pathosystems, races of $X$. translucens have not been identified (Büttner and Bonas 2003; Waney et al. 1991). Significant host-strain interactions have been described between $X$. translucens pv. graminis and Lolium multiflorum (Kölliker et al. 2006), but the lack of significant host genotype-pathogen strain interactions in another study suggests that BLS resistance in L. multiflorum is broadly effective (Wichmann et al. 2011). Although strains of X. translucens pv. undulosa and $X$. translucens pv. translucens vary in virulence (Adhikari et al. 2012a, b; Curland et al. 2018), studies aiming to identify differential interactions with host genotypes have produced inconsistent conclusions. One greenhouse study of $89 \mathrm{X}$. translucens strains from barley, wheat, triticale, and rye and 19 wheat cultivars revealed no significant bacterial strain and plant genotype interactions (Milus and Chalkley 1994). In contrast, evidence for strainplant genotype interactions was found in a study that included 29 strains of $X$. translucens pv. undulosa and 12 wheat cultivars (Adhikari et al. 2012a, b). Raja et al. (2010) detected qualitative differences in virulence among 10 strains of $X$. translucens pv. undulosa as well as differences in BLS susceptibility in six wheat varieties; however, the interaction between strain and variety was not evaluated statistically. A significant strain-cultivar interaction has been detected in a study of $>500$ triticale accessions inoculated with two virulent strains of $X$. translucens pv. undulosa (Sapkota et al. 2018). It is not yet known if the BLS resistance in triticale confers resistance to a broad range of $X$. translucens pv. undulosa strains.

The goals of this study were to gain insight on genotypic and phenotypic variation within and between populations of $X$. translucens at the field scale and assess plant genotype interactions with bacterial strains of known STs and virulence. Studies were designed to test the hypothesis that populations of $X$. translucens are uniform within and between fields of wheat and barley. To evaluate pathogen diversity, representative populations of $X$. translucens were obtained from naturally infected fields of wheat and barley exhibiting symptoms of BLS. MLSA was combined with greenhouse assays to identify strains to pathovar and assess virulence, whereas MLST and diversity analyses were applied to examine the frequency and diversity of STs within and across sample sites. Additionally, we measured the effects of pathovar and strain on field-level disease reactions of a subset of barley and wheat germplasm varying in resistance to BLS. This study provides, for the first time, evidence of significant genetic and phenotypic diversity occurring within well-defined field-scale populations of $X$. translucens pv. undulosa and X. translucens pv. translucens. MLST can be applied in the future for identifying shifts in prevalent STs of $X$. translucens at the local, regional, and global scales.

\section{MATERIALS AND METHODS}

Field sampling and isolation of the genus Xanthomonas. Leaves with BLS symptoms from natural infections were collected from two wheat and two barley farmers' fields in Minnesota. At each location, 25 samples of individual leaves were collected along a specified grid; 5 samples were collected along five transects for a total of 25 samples. Each transect was about $90 \mathrm{ft}$ long and $60 \mathrm{ft}$ apart, with the first and last transects no closer than $50 \mathrm{ft}$ from the edge of the field. Barley samples were collected from two sites: Alvarado, Minnesota (B1; 23 July 2015) and Karlstad, Minnesota (B2; 27 July 2015). Wheat samples were collected from two sites: Euclid, Minnesota (W1; 22 July 2015) and Red Lake Falls, Minnesota (W2; 23 July 2015).

Bacteria in plant samples were isolated on Wilbrink's Agar (WBA) (Sands et al. 1986), which favors growth of the genus Xanthomonas. One individual isolate per sample was selected based on colony morphology typical of the genus Xanthomonas, subcultured to purity, and stored in nutrient broth yeast extract (NBY)glycerol at $-80^{\circ} \mathrm{C}$. A small portion of each culture was suspended in $1 \mathrm{ml}$ of Tris EDTA buffer and stored at $-20^{\circ} \mathrm{C}$ for subsequent DNA extraction.

Pathogenicity and virulence tests. Pathogenicity and relative virulence of bacterial strains were evaluated in planta. The bacteria evaluated included 89 strains collected from two wheat and two barley fields in 2015 and representative type and pathotype strains from Belgium Co-ordinated Collections of Micro-organisms Laboratorium voor Microbiologie, Universiteit Gent (BCCM/LMG): $X$. translucens pv. translucens LMG876 (type), X. translucens pv. undulosa LMG892 (pathotype), X. translucens pv. secalis LMG883 (pathotype), and X. translucens pv. cerealis LMG679 (pathotype). Also included were strains CIX43, CIX84, and CIX41 to represent the previously described $X$. translucens pv. translucens clades A, B, and C, respectively (Curland et al. 2018). To prepare inoculum, bacterial cells were grown from freezer stocks on WBA for 3 days and subcultured to produce bacterial lawns on WBA. Bacterial cells were suspended in sterile $0.85 \% \mathrm{NaCl}(\mathrm{wt} / \mathrm{vol})$ buffer to achieve approximately $10^{7} \mathrm{CFU} / \mathrm{ml}$ (optical density $(\mathrm{OD})_{540}=0.01$ ).

Wheat (hard red spring wheat cultivar RB07) and barley (six-row cultivar Quest), varieties used in previous studies, were sown in cone-tainers filled with a 50:50 mix Sunshine MPV soilless media (Sun Gro Horticulture) and steam-sterilized field soil. Three seeds were planted per cone at a depth of 1.5 to $2.0 \mathrm{~cm}$ and fertilized with Osmocote Classic fertilizer (14:14:14 NPK (nitrogen phosphorous potassium)). Plants were grown at 18 to $22^{\circ} \mathrm{C}$ with $16 \mathrm{~h}$ of supplemental lighting provided by high-pressure sodium lamps. Two leaves per cone were inoculated via leaf infiltration with a needleless syringe at seedling (three- to five-leaf) stage. Control plants were inoculated with sterile saline buffer. The greenhouse temperature was increased to 25 to $27^{\circ} \mathrm{C}$ immediately after plant inoculations to encourage optimal bacterial growth. For each treatment, three replications were included, and the entire experiment was conducted twice. Character states associated with pathogenicity (water soaking, chlorosis, and no symptoms) were recorded 5 days postinoculation (dpi). Lesion lengths (centimeters) were measured and recorded $9 \mathrm{dpi}$ as a quantitative measurement of virulence. Virulence data were transformed by taking the square root of the lesion length (centimeters) to normalize the data (Curland et al. 2018). Data for barley and wheat field-collected strains were analyzed separately. The inoculated host (barley or wheat), field (B1/B2 or W1/W2), and trial (trial 1 or 2) were fit with multiple regression models for analysis of variance (ANOVA).

DNA extraction, amplification, and sequencing. Bacterial cells were grown on WBA for 3 days from freezer stocks and spread onto WBA to produce bacterial lawns. DNA was extracted using the DNeasy Blood and Tissue Kit (Qiagen). Regions of four housekeeping genes ( $r p o D$, dnaK, fyuA, and $g y r B$ ) were amplified and sequenced according to previous methods (Curland et al. 2018; Young et al. 2008). PCR products were submitted to Molecular Cloning Laboratories (San Francisco, CA) for purification and Sanger sequencing.

MLSA. CLC Main Workbench 7 (Qiagen) was used to assemble, align, and trim sequences to the following fragment lengths according to Zacaroni et al. (2012): rpoD (674 nucleotides), dnaK (762 nucleotides), fyuA (522 nucleotides), and gyrB (687 nucleotides). Sequences were concatenated for a final length of 2,645 nucleotides. Model testing was conducted through CLC Main Workbench 7 on 
individual loci and concatenated sequence data. The general timereversible $(\mathrm{GTR}+\mathrm{G}+\mathrm{T})$ model was used in all tree constructions. The program Bayesian Evolutionary Analysis Sampling Trees (BEAST 1.8.2) (Drummond et al. 2012) was used for Bayesian Markov Chain Monte Carlo (MCMC) analyses assuming a strict molecular clock and 10 million generations. The output was analyzed with Tracer v1.6.0 (Rambaut et al. 2018) and visualized in FigTree v1.4.2 (http://tree.bio.ed.ac.uk/software/figtree).

MLST. Haplotype data were generated in DnaSP v5 for each locus and concatenated sequences, and they were used to assign the number of unique alleles at each locus and STs to concatenates, respectively (Rozas et al. 2003). Relatedness of STs was calculated to generate a minimum spanning tree in PHYLOViZ 2.0 (Francisco et al. 2012).

Analysis of molecular variance. To detect population differentiation using the multiple sequence alignments in the barley and wheat isolates, an analysis of molecular variance (AMOVA) was conducted (Excoffier et al. 1992). The differentiation tests were performed in $\mathrm{R}$ ( $\mathrm{R}$ Core Team 2013) using the package poppr (Kamvar et al. 2014). The AMOVA test was conducted using the total genetic variation from the multiple sequence alignments and partitioned at two levels: both across and within collected isolates at field sites. The significance of the variation was tested using 999 permutations.

Field evaluation of bacterial strain $\times$ plant variety interactions. Field trials to evaluate disease severity caused by $X$. translucens $\mathrm{pv}$. translucens and $X$. translucens $\mathrm{pv}$. undulosa on barley and wheat, respectively, were conducted in 2015 and 2016. Four barley and four wheat lines were included. Each line had been previously evaluated for field-level resistance to BLS (Anderson et al. 2014; Smith et al. 2014) (K. Smith, personal communication). Barley lines included Maja and Tradition (susceptible) as well as ND26891 and MW11S2033-008 (resistant). Wheat lines included WB Mayville and RB07 (susceptible) as well as Prevail and Breaker (resistant). Four previously described strains of $X$. translucens pv. translucens (CIX29, CIX34, CIX41, and CIX76) originating from barley were evaluated on the barley lines. Four previously described strains of X. translucens pv. undulosa (CIX50, CIX53, CIX104, and CIX107) originating from wheat were evaluated on the wheat lines (Curland et al. 2018) (Table 1). Row plots were planted on the University of Minnesota's St. Paul campus in late May each year. The randomized complete block design contained four replications. The wheat and barley studies were planted side by side in the field and treated as separate experiments in nonirrigated fields. Each 4-ft block contained four 6-ft-long rows separated by 4-ft alleys. Each row within a block was planted with one of the four varieties used in each experiment so that each block contained all four varieties of either wheat or barley randomized within the block. Treatments were applied in a split plot design, with each block treated with one of four strains specific to either barley or wheat (Table 1). To minimize cross-contamination of strains, blocks were separated by buffers of eight 1-ft rows of filler. In the wheat experiment, barley (Quest) was planted as fill. In the barley experiment, wheat (cultivar Samson) was planted as fill.

Bacterial inoculum for field trials was initiated from freezer stocks of each strain grown on plates of WBA (Sands et al. 1986). After a 4- to 5-day incubation period at $27^{\circ} \mathrm{C}$, single colonies were subcultured on WBA as a nine-streak bacterial lawn, and they were incubated for 3 days at $27^{\circ} \mathrm{C}$. The inoculum was prepared in the field by washing cells from one 3-day-old bacterial lawn into 3 liters of saline buffer $(0.85 \% \mathrm{wt} / \mathrm{vol})$. This yielded an approximate concentration of $10^{8} \mathrm{CFU} / \mathrm{ml}$. Plants were spray inoculated with a gas-powered backpack sprayer at the tillering stage (on 22 June 2015 and 17 June 2016). X. translucens pv. undulosa strains CIX50, CIX53, CIX104, and CIX107 were applied to the wheat lines, and $X$. translucens pv. translucens strains CIX29, CIX34, CIX41, and CIX76 were applied to the barley lines. Each inoculation trial included replications of noninoculated plots and mock trials sprayed with sterile saline buffer $(0.85 \% \mathrm{wt} / \mathrm{vol})$.
Disease severity ratings were assessed at about soft dough stage on 7 and 17 July 2015 and 24 June and 1 July 2016. Data collected included leaf disease severity (percentage of leaves with symptoms within plot) and height of disease within the plant canopy (scale from 0 to 9 , with 9 indicating symptoms present at the top and throughout the plant canopy). A disease severity rating was calculated based on leaf severity and plant canopy ratings according to a previously validated method (Kandel et al. 2012). Data collected on 7 July 2015 and 1 July 2016 were analyzed in R using multiple regression models for ANOVA and least significant difference test (Fisher's least significant difference) for mean separation tests.

\section{RESULTS}

Phylogeny, pathogenicity, and identity of Xanthomonas strains obtained from naturally infected wheat and barley fields. Of the 100 leaf samples collected across four fields sites ( 25 samples per field), a total of $89 X$. translucens isolates were obtained: 25 from W1, 21 from W2, 24 from B1, and 19 from B2. Five leaf samples from B2 did not yield Xanthomonas-like bacteria, even after multiple isolations, and therefore, those samples were excluded from analysis. A small group of isolates (B1.24, B2.22, W2.7, W2.19, W2.22, and W2.24) was omitted from further study owing to insufficient amplification across all four MLSA loci. Based on NCBI BLAST analyses of sequences of select amplicons from this group, it was determined that these isolates belonged to the genus Xanthomonas but not to the species $X$. translucens.

Phylogenetic analyses revealed all strains of $X$. translucens from wheat grouped together and all strains from barley grouped together (Fig. 1). Two distinct clades within $X$. translucens pv. undulosa were further identified. One $X$. translucens pv. undulosa clade contained the pathotype strain LMG892 and 31 strains from W1 and $\mathrm{W} 2$. The other clade contained 15 strains, all but one of which were from W1 (Fig. 1). Three clades of X. translucens pv. translucens were identified. Clade Xtt A included pathotype strain LMG876 and reference strain CIX43. Clade Xtt B included reference strain CIX84. Clade Xtt C included reference strain CIX41. Strains collected from B1 and B2 were distributed across all three X. translucens pv. translucens clades (Xtt A, Xtt B, and Xtt C), suggesting genetic diversity within each field (Fig. 1 and Table 2). As previously reported by Curland et al. (2018), the Xtt A group, which included a total of 11 strains from B1 and B2, was most closely related to the $X$. translucens $\mathrm{pv}$. undulosa clade. Thirty-one barley strains belonged to Xtt B and Xtt $\mathrm{C}$, which diverged before the X. translucens pv. undulosa node. One barley strain, B2.5, grouped with the pathotype strain of $X$. translucens pv. cerealis: LMG679.

All 46 strains of $X$. translucens from wheat produced expanding, water-soaked lesions on wheat and expanding, chlorotic lesions on barley seedlings within 5 days of inoculation (Supplementary Fig.

TABLE 1. Host of origin, clade, and sequence types of Xanthomonas translucens strains used in field inoculations of wheat and barley lines

\begin{tabular}{llll}
\hline Pathovar and strain & Host $^{\mathrm{a}}$ & Clade & ST $^{\mathrm{b}}$ \\
\hline X. translucens pv. translucens & & & \\
CIX29 & Barley & Xtt B & 43 \\
CIX34 & Barley & Xtt A & 25 \\
CIX41 & Barley & Xtt C & 23 \\
CIX76 & Barley & Xtt A & 31 \\
X. translucens pv. undulosa & & & \\
CIX50 & Wheat & Xtu & 36 \\
CIX53 & Wheat & Xtu & 30 \\
CIX104 & Wheat & Xtu & 36 \\
CIX107 & Wheat & Xtu & 36 \\
\hline
\end{tabular}

a Host from which the strain was initially isolated.

b Sequence type (Curland et al. 2018). 


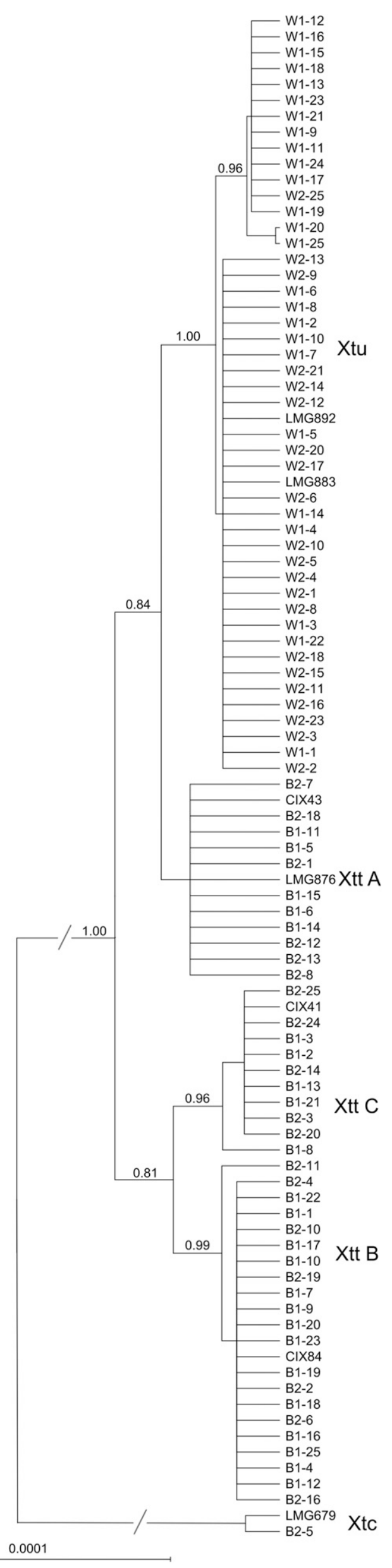

S1). In contrast, all 43 strains from barley produced water-soaked lesions in barley seedlings and chlorotic lesions that did not expand far beyond the area of infiltration in wheat seedlings (Supplementary Fig. S1). X. translucens pv. translucens-type strain LMG876 produced small chlorotic lesions on wheat, and it produced water-soaked lesions with some chlorosis on barley, whereas pathotype strain $X$. translucens pv. undulosa LMG892 incited long, water-soaked lesions on wheat and lesions on barley that were expanding yet only chlorotic. $X$. translucens pv. secalis pathotype strain LMG883 produced water soaking on wheat, but it was asymptomatic on barley. $X$. translucens pv. cerealis pathotype LMG679 strain produced chlorosis on barley and wheat. Seedlings inoculated with sterile buffer showed no symptoms.

Based on phylogeny and in planta character states observed in wheat and barley, all 46 strains from wheat were identified as $X$. translucens pv. undulosa (Table 2). Similarly, 43 strains from barley were confirmed as X. translucens pv. translucens (Table 2). One strain, B2.5 from field B2, was identified as $X$. translucens pv. cerealis and showed moderate virulence on both wheat and barley (Table 2).

Genetic diversity within and between populations of $X$. translucens from different fields. Among the 25 $X$. translucens strains from W1, four STs were identified, whereas six STs were detected within the 21 strains from W2 (Fig. 2 and Table 2). Three STs were common between wheat fields: ST 36, 38, and 54, of which ST 36 is also the predicted founder ST for the Xtu group (Fig. 2). Six STs were characterized among the 24 strains from B1, and seven STs were identified within the 19 strains from B2. ST 23, 24, and 43 and founder ST 49 were found across both barley fields (Fig. 2 and Table 2). Different STs were dominant within fields: ST 38 was most frequent in W1 (56\%), whereas ST 36 was most common in W2 (57.1\%) (Fig. 2 and Table 2). ST 43 was dominant in B1 (58.3\%), whereas STs were more evenly distributed within B2, with ST 43 most common at $31.6 \%$ and ST 23 comprising $26.3 \%$ of the samples (Fig. 2 and Table 2).

AMOVA based on the strains from barley fields indicated that a majority of the variation $(97.75 \%)$ occurred within the population, whereas the variations among locations were minor at $2.25 \%$ (Table 3). This indicates that the variation between field collection sites was not significant, because a large amount of variation is explained within the populations, indicating no real population structure. The same type of AMOVA was conducted using the fieldcollected wheat strains as well. For the wheat strains, again the majority of variation $(76.02 \%)$ occurred within the populations, but among location, variation was higher than in barley $(23.98 \%)$ (Table 3$)$. This variation is significant $(P<0.05)$ and indicated that, unlike barley, there was population structure within the wheat strains. There was significant diversity of strains between the collection fields.

Relative virulence of strains from different hosts and fields. In general, strains isolated from barley produced significantly longer lesions on barley than on wheat $(P<0.001)$ (Fig. 3). In contrast, strains isolated from wheat produced lesions that were similar in length in both wheat and barley $(P=0.739)$, with a few strains associated with longer lesions on barley than on wheat (Fig. 3). Strains from W1

\section{$<$}

Fig. 1. Bayesian tree generated from the concatenated sequences of four housekeeping genes (rpoD, dnaK, fyuA, and gyrB) (Young et al. 2008). This analysis includes 89 strains of Xanthomonas translucens collected in 2015 from two wheat fields $(n=46)$ and two barley fields $(n=43)$; strains representing previously described X. translucens pv. translucens clades Xtt A (CIX43), Xtt B (CIX84), and Xtt C (CIX41) (Curland et al. 2018); and type and pathotype strains from the Belgium Co-ordinated Collections of Micro-organisms Laboratorium voor Microbiologie, Universiteit Gent (BCCM/LMG) culture collection $\left(\mathrm{LMG679} 9^{\mathrm{PT}}=X\right.$. translucens $\mathrm{pv}$. cerealis, $\mathrm{LMG} 883^{\mathrm{PT}}=X$. translucens $\mathrm{pv}$. secalis, LMG892 ${ }^{\mathrm{PT}}=X$. translucens pv. undulosa, and LMG876 ${ }^{\mathrm{T}}=X$. translucens pv. translucens). Posterior probabilities $\geq 0.7$ are displayed at nodes. The first two characters in strain names indicate host (B, barley; W, wheat) and field number (one or two). 
differed in aggressiveness (measured as lesion length on both wheat and barley) from strains collected from W2 $(P<0.001)$ (Fig. 4). In barley, lesion lengths of strains from B1 versus B2 were significantly different $(P=0.005)$ than the wheat field strains (Fig. 4).

The effect of ST and $X$. translucens pv. translucens clade on lesion length in both wheat and barley was evaluated via ANOVA of square root-transformed lesion length values. For $X$. translucens $\mathrm{pv}$. translucens, strains representing the three most common STs (ST 23, 24, and 43) were analyzed (Fig. 3). The effect of ST 23, ST 24, and ST 43 on lesion length between treatments was not significant in both barley $(P=0.104)$ and wheat $(P=0.289)$. Additionally, for $X$. translucens pv. translucens, the clade (Xtt A, Xtt B, and Xtt C) did not significantly influence lesion length in barley $(P=0.118)$ or wheat $(P=0.289)$. For $X$. translucens pv. undulosa strains, three dominant STs (ST 34, 36, and 38) were evaluated for effect on lesions length and showed highly significant differences between STs in wheat $(P<0.001)$ and moderately significant differences in barley $(P=0.0193)$.

Bacterial strain $\times$ plant cultivar interactions under field conditions. To evaluate the potential interactions between strains of $X$. translucens and lines of wheat and barley, strains of $X$. translucens pv. translucens and $X$. translucens pv. undulosa of known ST and virulence were used in field inoculations of barley and wheat (Table 1) (Curland et al. 2018). Overall, disease severity in inoculated field plots was greater on wheat than on barley (Figs. 5 and $6)$. ANOVA indicated that, in both wheat $(\mathrm{df}=9, F$ value $=1.41)$ and barley $(\mathrm{df}=9, F$ value $=0.10)$, no significant isolate $\times$ cultivar interactions were detected $(P>0.1)$. In wheat, the isolate $(\mathrm{df}=3$, $F$ value $=15.97)$ had a significant impact on disease severity $(P<$ $0.001)$. However, disease severity on barley $(\mathrm{df}=3, F$ value $=3.23)$ was weakly affected by the strain $(P<0.05)$. To detect cross-contamination of isolates in plots, buffer plots were monitored after inoculation. In 2016, BLS was detected in buffer plots after first ratings were recorded, and therefore, subsequent ratings were not done. For both wheat $(\mathrm{df}=1$, $F$ value $=11.95)$ and barley $(\mathrm{df}=1, F$ value $=22.16)$, year significantly impacted disease severity $(P<0.001)$. This can be observed by the clear differences in the host response to various strains across the study, which was most dramatic in the susceptible barley variety Maja.

\section{DISCUSSION}

Knowledge of genotypic and phenotypic variation of strains associated with bacterial disease epidemics is essential in achieving broad-scale disease resistance. Consequently, the choice of bacterial strains used to challenge breeding materials in field and greenhouse disease-screening assays becomes an important consideration. Based on pathovar definitions, $X$. translucens pv. undulos $a$ is pathogenic on both wheat and barley, whereas X. translucens pv.

TABLE 2. Pathovar assignment, clade designations, and sequence types of strains representing populations of Xanthomonas translucens in naturally infected fields of barley and wheat fields

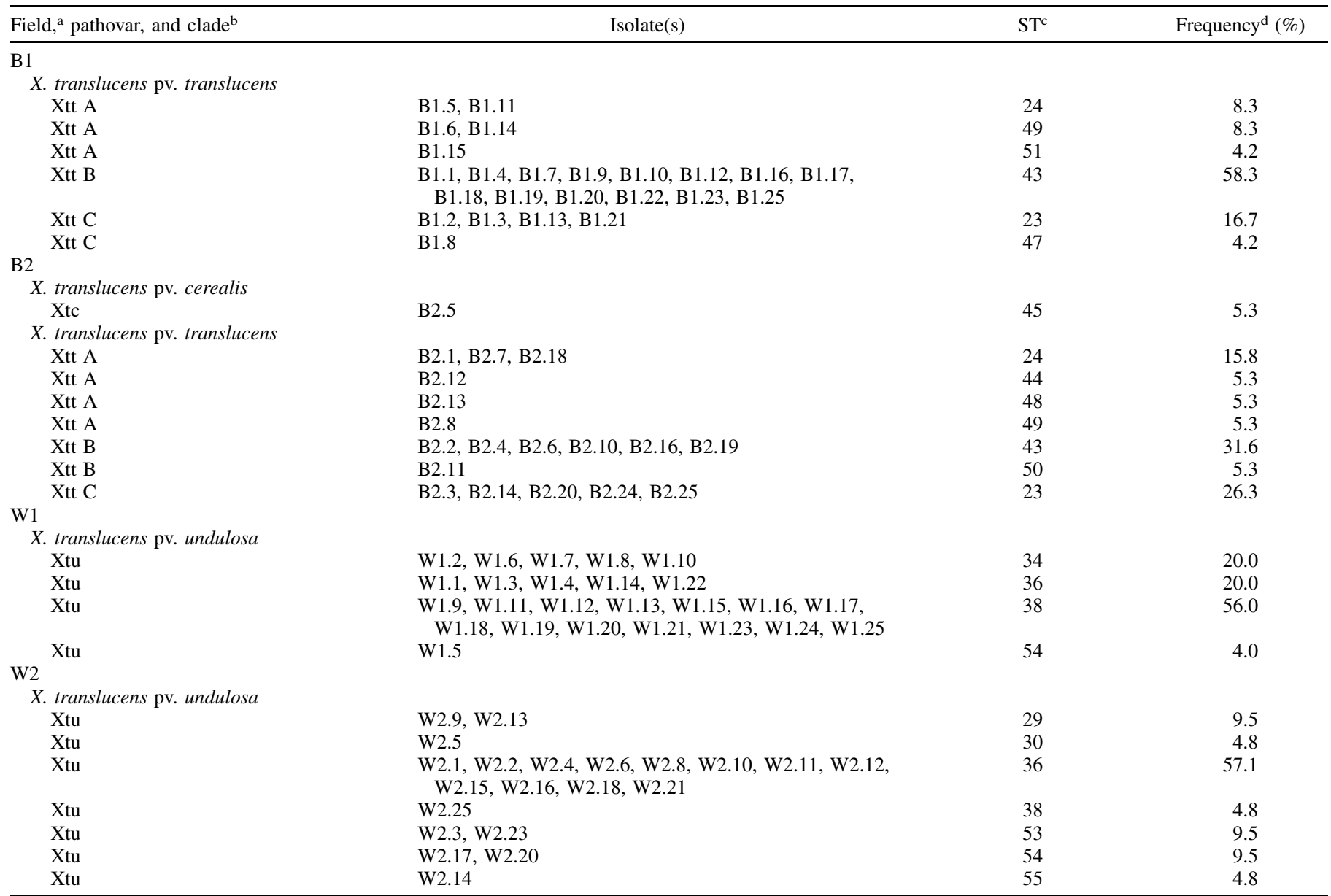

a B1 = barley field in Alvarado, Minnesota; B2 = barley field in Karlstad, Minnesota; W1 = wheat field in Euclid, Minnesota; W2 = wheat field in Red Lake Falls, Minnesota.

b Clade based on multilocus sequence analysis phylogeny as previously described (Curland et al. 2018).

c Sequence types (STs) based on polymorphisms within concatenated sequences of rpoD (674 nucleotides), dnaK (762 nucleotides), fyuA (522 nucleotides), and gyrB (687 nucleotides).

d Percentage of strains within the field site with a given ST. Total numbers of strains from each field site are 25, 21, 24, and 19 from W1, W2, B1, and B2, respectively. 
translucens is pathogenic only on barley (Jones et al. 1917; Hagborg 1942; Smith et al. 1919). Despite its pathogenicity on barley, $X$. translucens $\mathrm{pv}$. undulosa is infrequently detected in barley samples that are symptomatic for BLS (Bragard et al. 1995, 1997; Curland et al. 2018). Nonetheless, X. translucens pv. undulosa has been isolated from barley, and therefore, it should not be assumed that all isolates from barley are $X$. translucens pv. translucens. Pathovar identification is challenging, because it relies on host ranges studies, and there are no pathovar-specific biochemical or nucleic acid assays available. We have found that MLSA produces phylogenies that are consistent with classical pathovar definitions. Our results confirm that $X$. translucens pv. undulosa in wheat and X. translucens pv. translucens in barley are distinct pathosystems. Efforts to identify barley or wheat genotypes with BLS resistance should include pathovar-specific strains, because BLS resistance might be pathovar specific (i.e., resistance in barley to $X$. translucens pv. undulosa might not be conferred by the same loci conferring resistance to $X$. translucens pv. translucens).

Our findings show that natural infections of BLS caused by $X$. translucens pv. undulosa and $X$. translucens pv. translucens are not associated with a single strain of a given pathovar but rather, composite populations of multiple, genetically distinct strains within a field. A similar finding of coinfections was reported for Xanthomonas citri pv. citri populations at the microscale of individual cankers (Pruvost et al. 2019). Some key aspects of genetic diversity vary between the two $X$. translucens pathosystems. Phylogenetically, X. translucens pv. undulosa, with its single lineage, is genetically more homogenous overall than X. translucens pv. translucens, with its three distinct lineages. Similar lineages and genetic diversity were reported within a regional collection of $X$. translucens from wheat and barley (Curland et al. 2018) and in a whole-genome single-nucleotide polymorphism analysis of multiple strains from different hosts, countries, and years (Charkhabi et al. 2017). Another distinction, which we report here for the first time, is that there is a significant field-scale population structure of $X$. translucens pv. undulosa. Genetic diversity in this pathovar thus varies not only within the total collection of $X$. translucens pv. undulosa strains but also, by location. This implies that the population of $X$. translucens pv. undulosa in one wheat field with BLS can vary from the population of $X$. translucens pv. undulosa in another. Our results support previous findings of variation among $X$. translucens pv. undulosa populations at larger geographic scales (Adhikari et al. $2012 \mathrm{a}, \mathrm{b}$ ). In contrast, the population structure of $X$. translucens $\mathrm{pv}$. translucens does not seem to vary by location; however, it is possible that including a greater number of locations and thus, increasing the degrees of freedom in an AMOVA might improve detection of localized variation. It could also be that the level of genetic diversity across the three clades of $X$. translucens pv. translucens is large enough that population structures at the geographic scale might not be detectable. Seeds, weeds, and plant debris are considered inoculum
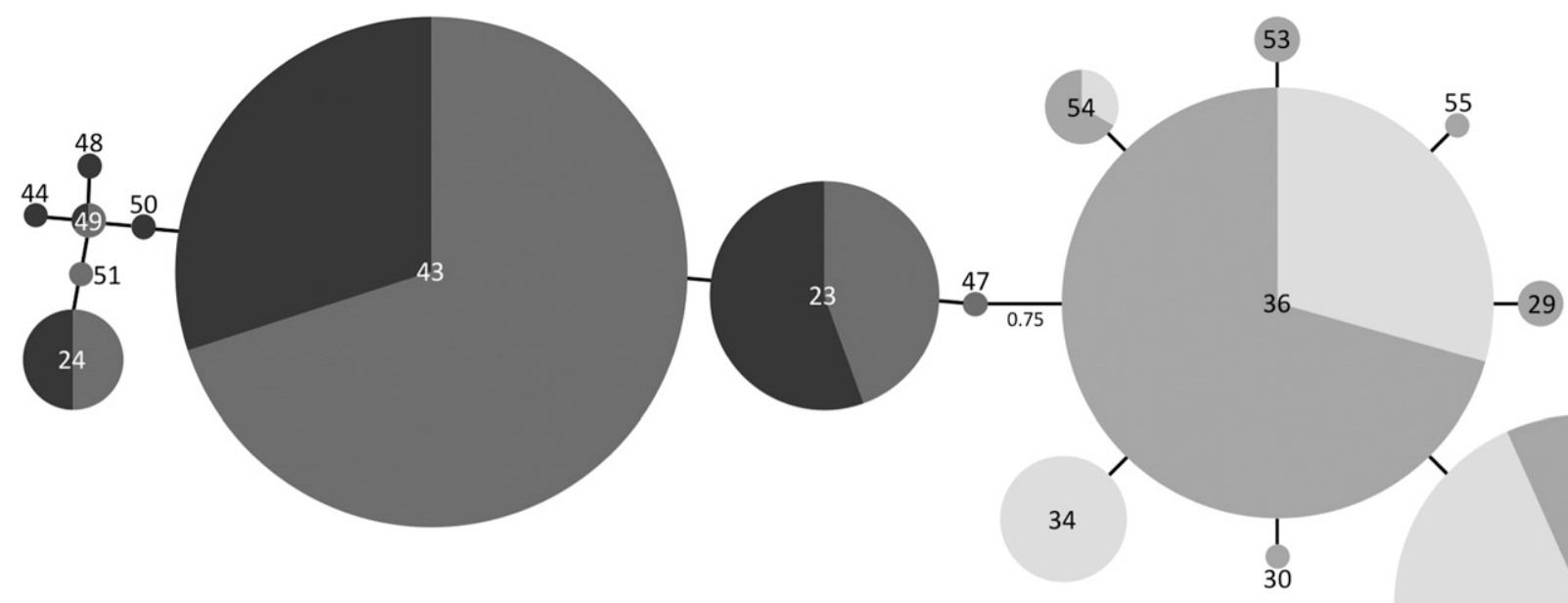

Barley Field 1

Wheat Field 1

Barley Field 2

Wheat Field 2

Fig. 2. Minimal spanning tree showing relatedness of 88 Xanthomonas translucens strains from two wheat and two barley fields based on sequence types (STs). Strain B2.5 was identified at $X$. translucens pv. cerealis and has four unique alleles for the loci used in this analysis; therefore, it was excluded from this figure. Each node represents a sequence type based on concatenated STs from four housekeeping genes ( $r p o D$, dnaK, fyuA, and gyrB). Sizes of nodes are relative to the number of individuals sharing the same ST. The relatedness between strains is indicated by relative distance as indicated by branch lengths. All but one branch represent the same relative distance of 0.25 , indicating a single-locus variance. The branch between STs 47 and 36 has relative distance of 0.75 (labeled as such), indicating a variance in three of the four loci used in this analysis.

TABLE 3. Analysis of molecular variance of genetic diversity within and between populations of Xanthomonas translucens pv. translucens isolated from two fields of barley and X. translucens pv. undulosa isolated from two fields of wheat

\begin{tabular}{|c|c|c|c|c|c|}
\hline Population and source of variation ${ }^{\mathrm{a}}$ & df & Sum squares & Percentage variation & $\Phi$ & $P$ value \\
\hline \multicolumn{6}{|l|}{ Barleyb } \\
\hline Between fields & 1 & 0.54 & 2.25 & 0.02 & 0.18 \\
\hline Within populations & 41 & 14.90 & 97.75 & - & - \\
\hline Between fields & 1 & 2.66 & 23.98 & 0.24 & 0.001 \\
\hline Within populations & 44 & 14.27 & 76.02 & - & - \\
\hline
\end{tabular}

${ }^{a}$ Based on multiple sequence alignments of amplified regions of $r p o D$, dnaK, fyuA, and gyrB.

b Total population size is 43 strains of $X$. translucens pv. translucens: 24 strains from B1 and 19 strains from B2.

c Total population size is 46 strains of $X$. translucens pv. undulosa: 25 strains from W1 and 21 strains from W2. 
sources for both $X$. translucens $\mathrm{pv}$. undulosa and X. translucens $\mathrm{pv}$. translucens, and therefore, differences in inoculum source are not an obvious explanation for the differences in population structure of these pathovars. The impact of inoculum source on genetic diversity of either pathovar is unknown. We speculate that the significant genetic diversity within $X$. translucens pv. translucens and $X$. translucens pv. undulosa could impact efforts to develop durable host resistance in wheat and barley.

In addition to finding evidence of genetic diversity, our study corroborates and extends previous reports of significant phenotypic diversity as measured by virulence within $X$. translucens (Adhikari et al. 2012a, b; Charkhabi et al. 2017; Duveiller et al. 1992; Rademaker et al. 2006; Sapkota et al. 2018). In this Minnesota study, virulence varied significantly by strain. Wheat strains produced mean lesions lengths between 1.5 and $6.2 \mathrm{~cm}$ in barley and between 1.3 and $5.8 \mathrm{~cm}$ in wheat. Barley strains produced mean lesion lengths between 2.5 and $5.8 \mathrm{~cm}$ in barley. This type of phenotypic variation was also detected within populations collected from a single field. In inoculated barley leaves, virulence of $X$. translucens pv. translucens strains from B1 ranged from 2.8 to $5.8 \mathrm{~cm}$, whereas virulence of strains from B2 ranged from 2.5 to $4.8 \mathrm{~cm}$. Similar ranges of virulence in wheat and barley were detected in strains of $X$. translucens pv. undulosa within each of two wheat fields. Overall virulence of strains can also differ between fields. For example, we found that the average virulence for W1 strains was greater than that of strains from W2. Similarly, average virulence for B1 strains was greater than that of strains from B2. Information on the specific varieties of wheat and barley planted in $\mathrm{B} 1, \mathrm{~B} 2, \mathrm{~W} 1$, and W2 was not available to us. It is possible that the varieties varied in disease resistance or susceptibility and that this might have influenced average virulence of isolates within a field. Future studies based on pathogen collections obtained from naturally infected, replicated field trials of wheat and barley varieties varying in BLS susceptibility are warranted.

Although genetic diversity is common in populations of $X$. translucens pv. undulosa and X. translucens pv. translucens, certain STs in each are more prevalent (Curland et al. 2018) (K. E. Ledman, R. D. Curland, C. A. Ishimaru, and R. Dill-Macky, unpublished data). The two most commonly identified STs of $X$. translucens pv. undulosa (ST 36 and ST 38) and X. translucens pv. translucens (ST 23 and ST 43) in this study were also the most common in the MLST study of a collection of strains from the Upper Midwest (Curland et al. 2018). The pathotype of $X$. translucens pv. undulosa, LMG892, which was originally isolated in 1966 from Triticum turgidum in Canada, also has been assigned to ST 36 (Curland et al. 2018). Consistent with our previous findings, here we again identified

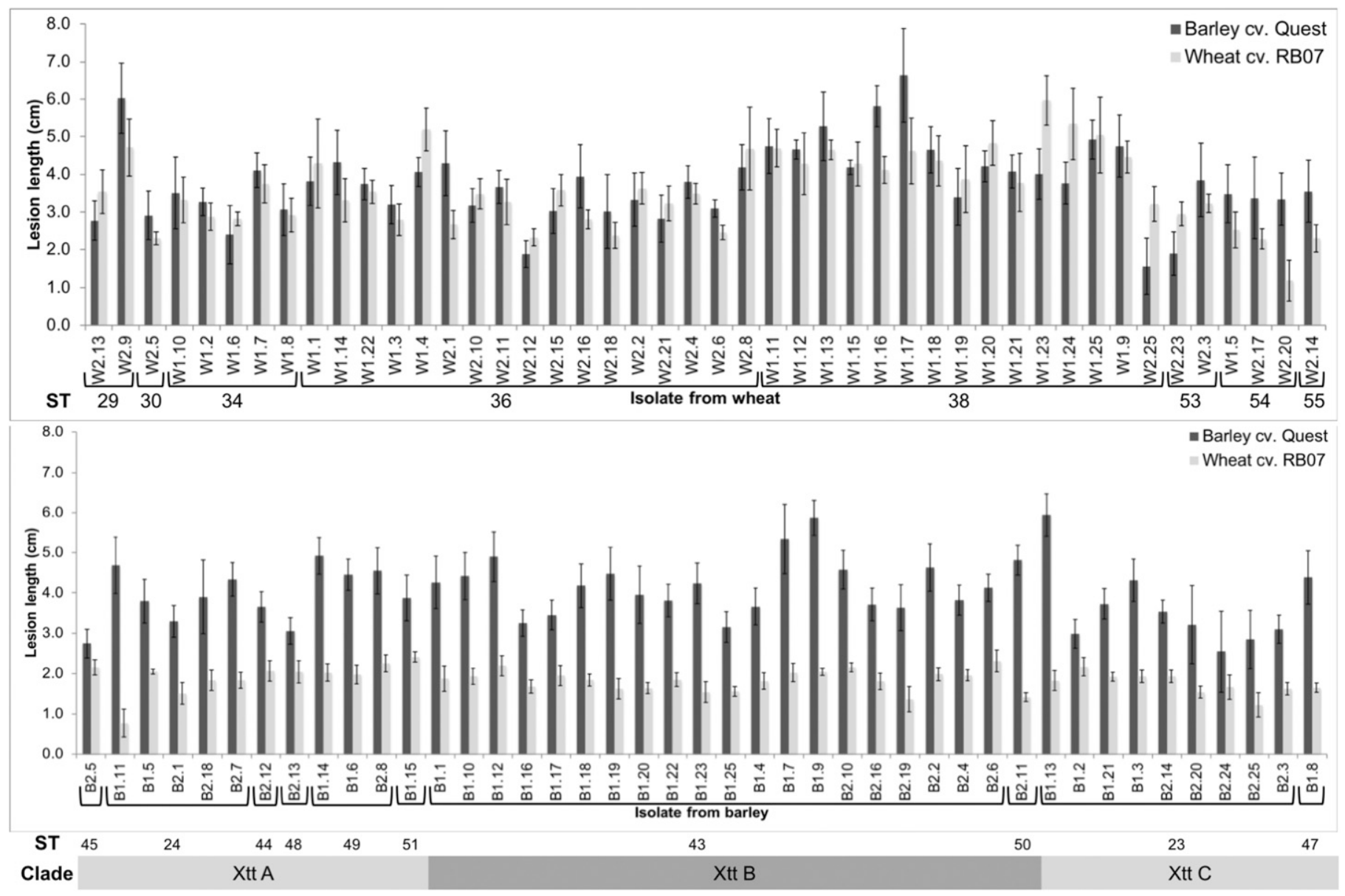

Fig. 3. Histograms of virulence measured as lesion length (centimeters) of 89 strains collected from two wheat fields (upper graph; $n=46)$ and two barley fields (lower graph; $n=43$ ). Strains W1.X and W2.X are from wheat fields 1 and 2, respectively, whereas strains B1.X and B2.X are from barley fields 1 and 2, respectively. Sequence type (ST) and clade (barley only) as determined by analysis of the concatenated sequence of segments of $r p o D$, dnaK, fyuA, and gyrB are indicated below each graph. Isolate B2.5 from barley ( $\mathrm{ST}=45)$ was identified as Xanthomonas translucens pv. cerealis and is, therefore, not included in the Xtt clades. Seedlings at the three- to four-leaf stage of moderately susceptible cultivars of wheat (cultivar RB07) and barley (cultivar Quest) plants were inoculated with a bacterial suspension $\left(10^{7} \mathrm{CFU} / \mathrm{ml}\right.$, optical density $\left.(\mathrm{OD})_{620}=0.01\right)$ via leaf infiltration with a blunt-ended syringe. Lesion length measurements were recorded 10 days postinoculation. To retain biological relevance, nontransformed values are presented here. Error bars indicate standard error based on nontransformed lesion lengths. The three dominant STs $(34,36$, and 38) of $X$. translucens pv. undulosa produced significantly different lesion lengths in wheat $(P<$ $0.001)$ and barley $(P=0.0193)$. Lesion lengths produced by the three most common STs $(23,24$, and 43$)$ of $X$. translucens pv. translucens were not significantly different in barley $(P=0.104)$ or wheat $(P=0.289)$. Clades of $X$. translucens pv. translucens $(\mathrm{Xtt} \mathrm{A}, \mathrm{Xtt} \mathrm{B}$, and $\mathrm{Xtt} \mathrm{C})$ also did not produce significantly different lesion lengths in barley $(P=0.118)$ or wheat $(P=0.289)$. 
ST 36 as the predicted founder ST for X. translucens pv. undulosa. In contrast, ST 22, which was previously assigned to the type strain $X$. translucens pv. translucens LMG 876, was not detected among strains in this study or a previous study (Curland et al. 2018). LMG876 was first isolated in 1933 from Hordeum vulgare in Minnesota. It is possible that frequently occurring STs have heretofore unidentified fitness or virulence traits affecting bacterial survival or spread across diverse geographic regions and plant germplasm. The finding of significant differences in virulence among STs of $X$. translucens pv. undulosa supports this hypothesis.

BLS severity in the field is the result of multiple interacting factors. Under field conditions, we found that year and bacterial strain have significant effects on BLS severity and that strains can produce different disease severities in different years. These findings together with the genetic and phenotypic diversity of $X$. translucens populations within fields add to the challenge of breeding for high-level BLS resistance. Nevertheless, in this study, we did observe lower disease severities overall on wheat and barley lines previously identified as resistant to BLS. In previous studies and the field study reported here, a significant interaction between bacterial strain and plant genotype was not detected (Milus and Chalkley 1994; Tillman et al. 1996). Our experiments were conducted under field conditions, because field studies were expected to more closely mimic natural infections. Doing so imposed practical limitations on the number of strains and plant genotypes that could be evaluated. To ensure that adequate pathogen diversity was represented, we included strains classified by MLSA to
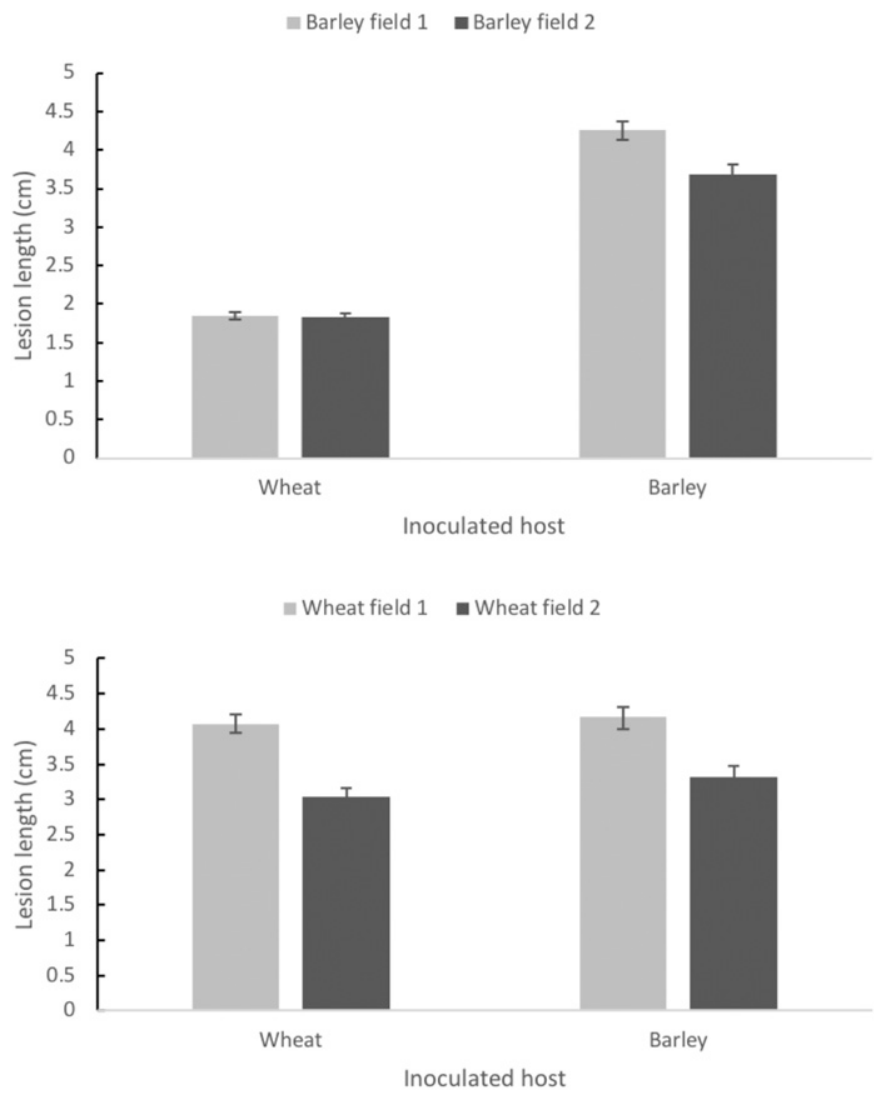

Fig. 4. Combined average lesions lengths (centimeters) produced by Xanthomonas translucens strains after leaf infiltration of greenhouse-grown seedlings of wheat and barley with 43 strains collected from two naturally infected barley fields (upper panel) and 46 isolates collected from two naturally infected wheat fields (lower panel). Seedlings at the three- to four-leaf stage of moderately susceptible cultivars of wheat (cultivar RB07) and barley (cultivar Quest) plants were inoculated with a bacterial suspension $\left(10^{7} \mathrm{CFU} /\right.$ $\mathrm{ml}$, optical density $\left.(\mathrm{OD})_{620}=0.01\right)$ via leaf infiltration with a blunt-ended syringe. Lesion length measurements were recorded 10 days postinoculation. Error bars indicate standard error. represent different phylogenetic clades of $X$. translucens and strains classified by MLST to represent different STs within clades. Strains were also chosen to reflect different virulence capacities on wheat and barley (Curland et al. 2018). The intention for including three ST

Barley 2015

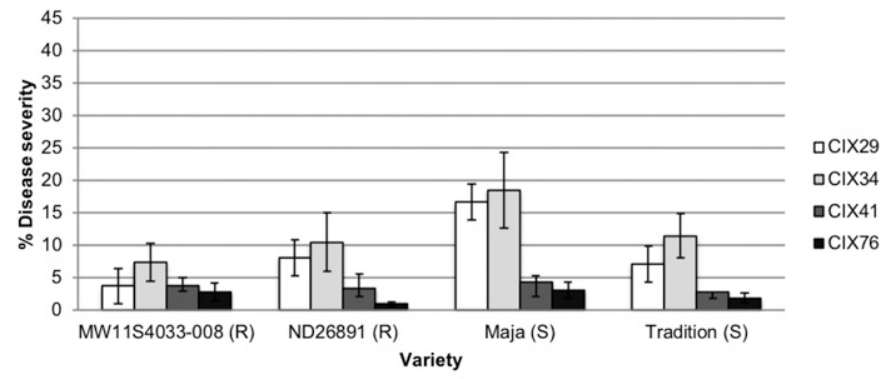

Barley 2016

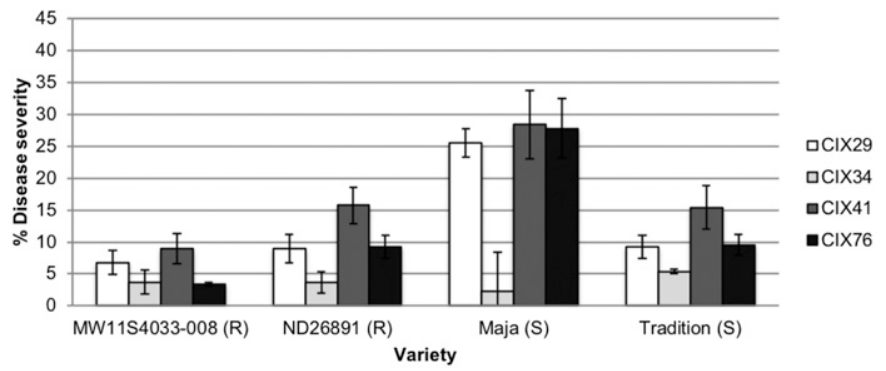

Fig. 5. Disease severity of bacterial leaf streak on two resistant (R; MW11S4033-008 and ND26891) and two susceptible (S; Maja and Tradition) lines of barley grown at the St. Paul campus research farm in 2015 and 2016. Field plots of barley were spray inoculated at tillering with different strains (CIX29, CIX34, CIX41, and CIX76) of Xanthomonas translucens pv. translucens originating from barley. Disease severity was calculated according to Kandel et al. (2012) based on assessments taken 14 to 15 days postinoculation. Error bars indicate standard errors.

Wheat 2015

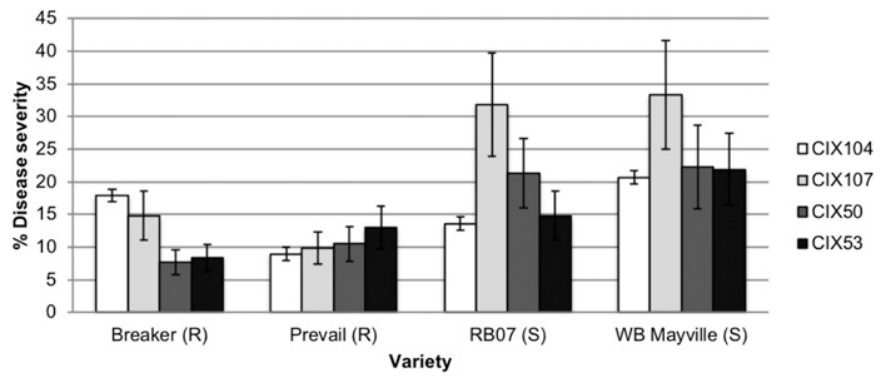

Wheat 2016

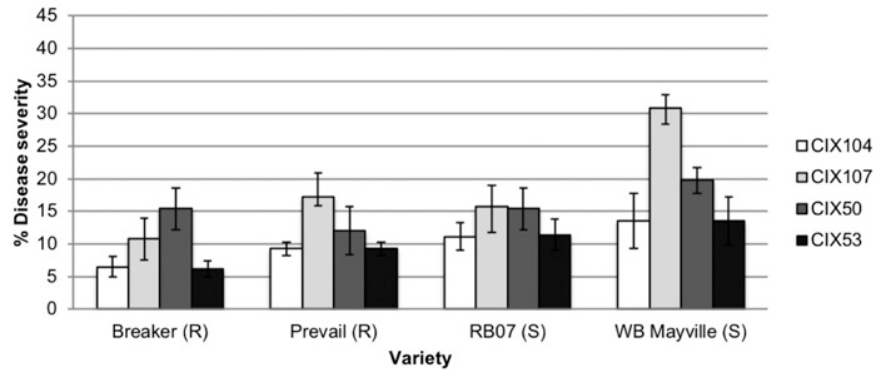

Fig. 6. Disease severity of bacterial leaf streak on two resistant (R; Breaker and Prevail) and two susceptible (S; RB07 and WB Mayville) lines of wheat grown at the St. Paul campus research farm in 2015 and 2016. Field plots of wheat were spray inoculated at tillering with different strains (CIX50, CIX53, CIX104, and CIX107) of Xanthomonas translucens pv. undulosa originating from wheat. Disease severity was calculated according to Kandel et al. (2012) based on assessments taken 14 to 15 days postinoculation. Error bars indicate standard error. 
36 strains of $X$. translucens pv. undulosa was to control for variation caused by ST-associated traits; however, that limited the possibility of observing ST-dependent ones. Another limitation in this study and other studies aimed at understanding the role of strain-cultivar interactions is that the genetic base of wheat and barley lines evaluated might have been too narrow to enable differentiation of strains of either pathovar. Broadening the scope of host germplasm to include triticale was critical in identifying high levels of BLS resistance conferred by Xctl (Sapkota et al. 2018; Wen et al. 2018). Future studies on the effect of pathogen diversity on Xct1-mediated disease resistance are warranted.

Phylogenies predicted by whole-genome sequencing or MLSA generally reflect pathovar designations of $X$. translucens pathovars, but it remains to be determined if MLSA and MLST can provide further meaningful biological differences among and within specific clades, such as Xtt A, Xtt B, and Xtt C. MLST uses the allelic differences across concatenated sequence fragments of housekeeping genes to assign STs to individuals (Maiden 2006). Because housekeeping genes are required for basic cellular functions and generally are not associated with pathogenicity, these genes are conserved among species and less subject to selective pressure. MLST is used widely for understanding diversity of bacterial plant pathogens and inferring epidemiological patterns of pathogen spread and population shifts (Croce et al. 2016; Fayette et al. 2016; Jacques et al. 2012; Sen et al. 2018). Although our studies have relied on primer-specific amplification of housekeeping genes, additional MLSA/MLST studies on regional and global collections will be increasingly obtainable by extracting sequence information from draft and complete genome depositories.

Molecular biology studies on pathogenesis of the barley/ $X$. translucens pv. translucens and wheat/barley/X. translucens pv. undulosa pathosystems are advancing rapidly. The availability of genome sequences and mutational studies of the pathogen is providing greater understanding of inter- and intrapathovar genetic differences contributing to virulence and host adaptation in X. translucens (Charkhabi et al. 2017; Hersemann et al. 2017; Langlois et al. 2017; Peng et al. 2016; Pesce et al. 2017). A noncanonical type 3 secretion system is present in $X$. translucens and required for full virulence through translocation of type 3 secretion system-dependent effectors (T3Es) (Büttner and Bonas 2003; Charkhabi et al. 2017; Peng et al. 2016). In many gramnegative plant pathogenic bacteria, T3Es contribute to effectortriggered immunity or effector-triggered susceptibility by directly or indirectly interacting with cognate plant resistance or susceptibility genes, respectively (Boch et al. 2014; Ma and Wang 2018). The repertoire of T3Es in X. translucens pv. undulosa, X. translucens pv. translucens, and $X$. translucens pv. cerealis consists of a conserved set of 23 T3Es and multiple variable T3Es (Peng et al. 2016).

Transcription activator-like effectors (TALEs), a specific class of type three secretion system (TTSS)-dependent effectors, are present and important in virulence of some Xanthomonas species, and thy are also present $X$. translucens pv. undulosa and $X$. translucens pv. translucens (Charkhabi et al. 2017; Jaenicke et al. 2016; Peng et al. 2016). Whole-genome comparisons of $X$. translucens $\mathrm{pv}$. undulosa showed two strains (one from the United States and one from Iran) that differ slightly in their effector repertoire of repeat-rich TALE genes. Importantly, two TALE genes, Tal2 and Tal4b, contribute to virulence in the Iranian strain, ICMP1 1055 (Charkhabi et al. 2017). The gene targets within wheat or barley of TALEs of $X$. translucens have not yet been identified. Additionally, it remains to be determined if phylogenies predicted by MLSA correlate with phylogenies predicted by sequence variation within loci under selective pressure, such as TALEs (Charkhabi et al. 2017). Future studies involving mutagenesis and whole-genome comparisons of well-characterized strains selected for pathovar, clade, ST, and virulence might be useful in facilitating identification of genes contributing to host preference and adaptation in $X$. translucens and to host resistance in wheat and barley.

\section{ACKNOWLEDGMENTS}

We thank Justin Stanton, Joe Wodarek, and Joe Stroot from the University of Minnesota's Crookston Campus for collecting the infected wheat and barley samples used in this study. Jim Anderson and Kevin Smith (Department of Agronomy, University of Minnesota, St. Paul) provided wheat and barley seed, respectively. We also thank Amar Elakkad, Beheshteh Zargaran, and Ruth Dill-Macky for support in planning and planting field experiments. We are grateful for technical support from Kristi Ledman, Lillian Garber, Erica Fealko, Jia Mikuls, and Emily Rankine.

\section{LITERATURE CITED}

Adhikari, T. B., Gurung, S., Hansen, J. M., and Bonman, J. M. 2012a. Pathogenic and genetic diversity of Xanthomonas translucens pv. undulosa in North Dakota. Phytopathology 102:390-402.

Adhikari, T. B., Gurung, S., Hansen, J. M., Jackson, E. W., and Bonman, J. M. 2012b. Association mapping of quantitative trait loci in spring wheat landraces conferring resistance to bacterial leaf streak and spot blotch. Plant Genome 5:1-16

Adhikari, T. B., Hansen, J. M., Gurung, S., and Bonman, J. M. 2011. Identification of new sources of resistance in winter wheat to multiple strains of Xanthomonas translucens pv. undulosa. Plant Dis. 95:582-588.

Alizadeh, A., Arlat, M., Sarrafi, A., Boucher, C. A., Barrault, G., and Alizadah, A. 1997. Restriction fragment length polymorphism analyses of Iranian strains of Xanthomonas campestris from cereals and grasses. Plant Dis. 81:31-35.

Alizadeh, A., Benetti, V., Sarrafi, A., Barrault, G., and Albertini, L. 1994. Genetic analysis for partial resistance to an Iranian strain of bacterial leaf streak (X. campestris pv. hordei) in barley. Plant Breed. 113:323-326.

Anderson, J., Wiersma, J., Reynolds, S., Green, M., Caspers, R., Kolmer, J., Jin, Y., Dill-Macky, R., and Ohm, J. 2014. Hard Red Spring Wheat Field Crop Trials Results. Minnesota Agriclutural Experiment Station, St. Paul, MN

Boch, J., Bonas, U., and Lahaye, T. 2014. TAL effectors: Pathogen strategies and plant resistance engineering. New Phytol. 204:823-832.

Bowden, R. L., and Percich, J. A. 1983. Etiology of bacterial leaf streak of wild rice. Phytopathology 73:640-645.

Bragard, C., Singer, E., Alizadeh, A., Vauterin, L., Maraite, H., and Swings, J. 1997. Xanthomonas translucens from small grains: Diversity and phytopathological relevance. Phytopathology 87:1111-1117.

Bragard, C., Verdier, V., and Maraite, H. 1995. Genetic diversity among Xanthomonas campestris strains pathogenic for small grains. Appl. Environ. Microbiol. 61:1020-1026.

Büttner, D., and Bonas, U. 2003. Common infection strategies of plant and animal pathogenic bacteria. Curr. Opin. Plant Biol. 6:312-319.

Charkhabi, N. F., Booher, N. J., Peng, Z., Wang, L., Rahimian, H., Shams-Bakhsh, M., Liu, Z., Liu, S., White, F. F., and Bogdanove, A. J. 2017. Complete genome sequencing and targeted mutagenesis reveal virulence contributions of Tal2 and Tal4b of Xanthomonas translucens pv. undulosa ICMP11055 in bacterial leaf streak of wheat. Front. Microbiol. 8: $1-17$.

Croce, V., Pianzzola, M. J., Durand, K., González-arcos, M., Jacques, M. A., and Siri, M. I. 2016. Multilocus sequence typing reveals high variability among Clavibacter michiganensis subsp. michiganensis strains affecting tomato crops in Uruguay. Eur. J. Plant Pathol. 144:1-13.

Cunfer, B. M., and Scolari, B. L. 1982. Xanthomonas campestris pv. translucens on triticale and other small grains. Phytopathology 72:683-686.

Curland, R. D., Gao, L., Bull, C. T., Vinatzer, B. A., Dill-Macky, R., van Eck, L., and Ishimaru, C. A. 2018. Genetic diversity and virulence of wheat and barley strains of Xanthomonas translucens from the Upper Midwestern United States. Phytopathology 108:443-453.

Drummond, A. J., Suchard, M. A., Xie, D., and Rambaut, A. 2012. Bayesian phylogenetics with BEAUti and the BEAST 1.7. Mol. Biol. Evol. 29: 1969-1973.

Duveiller, E., Bragard, C., and Maraite, H. 1997. Bacterial leaf streak and black chaff caused by Xanthomonas translucens. Page 25-47 in: The Bacterial Diseases of Wheat: Concepts and Methods of Disease Management. E. Duveiller, L. Fučíkovský, and K. Rudolph, eds. CIMMYT, Mexico City, Mexico.

Duveiller, E., Kandel, Y. R., Sharma, R. C., and Shrestha, S. M. 2005. Epidemiology of foliar blights (spot blotch and tan spot) of wheat in the plains bordering the Himalayas. Phytopathology 95:248-256.

Duveiller, E., van Ginkel, M., and Thijssen, M. 1992. Genetic analysis of resistance to bacterial leaf streak caused by Xanthomonas campestris pv. undulosa in bread wheat. Euphytica 66:35-43.

Excoffier, L., Smouse, P. E., and Quattro, J. M. 1992. Analysis of molecular variance inferred from metric distance among DNA haplotypes: 
Application to human mitochondrial DNA restriction data. Genet. Soc. Am. 491:479-491.

Fayette, J., Raid, R., Roberts, P. D., Jones, J. B., Pernezny, K., Bull, C. T., and Goss, E. M. 2016. Multilocus sequence typing of strains of bacterial spot of lettuce collected in the United States. Phytopathology 106: 1262-1269.

Forster, R. L., and Schaad, N. W. 1988. Control of black chaff of wheat with seed treatment and a foundation seed health program. Plant Dis. 72: 935-938.

Francisco, A. P., Vaz, C., Monteiro, P. T., Melo-Cristino, M., Ramirez, M., and Carrico, J. A. 2012. PHYLOViZ: Phylogenetic inference and data visualization for sequence based typing methods. BMC Bioinformatics 13:87.

Hagborg, W. A. F. 1942. Classification revision in Xanthomonas translucens. Can. J. Res. 20c:312-326.

Hersemann, L., Wibberg, D., Blom, J., Goesmann, A., Widmer, F., Vorhölter, F. J., and Kölliker, R. 2017. Comparative genomics of host adaptive traits in Xanthomonas translucens pv. graminis. BMC Genomics 18:35.

Jacques, M. A., Durand, K., Orgeur, G., Balidas, S., Fricot, C., Bonneau, S., Quillévéré, A., Audusseau, C., Olivier, V., Grimault, V., and Mathis, R. 2012. Phylogenetic analysis and polyphasic characterization of Clavibacter michiganensis strains isolated from tomato seeds reveal that nonpathogenic strains are distinct from C. michiganensis subsp. michiganensis. Appl. Environ. Microbiol. 78:8388-8402.

Jaenicke, S., Bunk, B., Wibberg, D., Spröer, C., Hersemann, L., Blom, J., Winkler, A., Schatschneider, S., Albaum, S. P., Kölliker, R., Goesmann, A., Pühler, A., Overmann, J., and Vorhölter, F. J. 2016. Complete genome sequence of the barley pathogen Xanthomonas pv. translucens DSM $18974^{\mathrm{T}}$ (ATCC19319'). Am. Soc. Microbiol. 4:1-2.

Jones, L., Johnson, A., and Reddy, C. 1917. Bacterial-blight of barley. J. Agric. Res. 11:625-643.

Kamvar, Z. N., Tabima, J. F., and Grünwald, N. J. 2014. Poppr: An R package for genetic analysis of populations with clonal, partially clonal, and/or sexual reproduction. PeerJ 2:e281.

Kandel, Y. R., Glover, K. D., and Osborne, L. E. 2015. Mapping quantitative resistance loci for bacterial leaf streak disease in hard red spring wheat using an identity by descent mapping approach. Euphytica 201:53-65.

Kandel, Y. R., Glover, K. D., Tande, C. A., and Osborne, L. E. 2012. Evaluation of spring wheat germplasm for resistance to bacterial leaf streak caused by Xanthomonas campestris pv. translucens. Plant Dis. 96: 1743-1748.

Kölliker, R., Kraehenbuehl, R., Boller, B., and Widmer, F. 2006. Genetic diversity and pathogenicity of the grass pathogen Xanthomonas translucens pv. graminis. Syst. Appl. Microbiol. 29:109-119.

Langlois, P. A., Snelling, J., Hamilton, J. P., Bragard, C., Koebnik, R., Verdier, V., Triplett, L. R., Blom, J., Tisserat, N. A., and Leach, J. E. 2017. Characterization of the Xanthomonas translucens complex using draft genomes, comparative genomics, phylogenetic analysis, and diagnostic LAMP assays. Phytopathology 107:519-527.

Ma, W., and Wang, Y. 2018. Focus on effector-triggered susceptibility. Mol. Plant-Microbe Interact. 31:5.

Maiden, M. C. 2006. Multilocus sequence typing of bacteria. Annu. Rev. Microbiol. 60:561-588.

Maraite, H., Bragard, C., and Duveiller, E. 2007. The status of resistance to bacterial diseases of wheat. Pages 37-49 in: Wheat Production in Stressed Environments. H. T. Buck, J. E. Nisi, and N. Salomon, eds. Springer, New York.

Milus, E. A., and Chalkley, D. B. 1994. Virulence of Xanthomonas campestris pv. translucens on selected wheat cultivars. Plant Dis. 78:612-615.

Peng, Z., Hu, Y., Xie, J., Potnis, N., Akhunova, A., Jones, J., Liu, Z., White, F. F., and Liu, S. 2016. Long read and single molecule DNA sequencing simplifies genome assembly and TAL effector gene analysis of Xanthomonas translucens. BMC Genomics 17:21.

Pesce, C., Jacobs, J. M., Berthelot, E., Perret, M., Vancheva, T., Bragard, C., and Koebnik, R. 2017. Comparative genomics identifies a novel conserved protein, HpaT, in proteobacterial type III secretion systems that do not possess the putative translocon protein HrpF. Front. Microbiol. 8:1177.

Pruvost, O., Boyer, K., Ravigné, V., Richard, D., and Vernière, C. 2019. Deciphering how plant pathogenic bacteria disperse and meet: Molecular epidemiology of Xanthomonas citri pv. citri at microgeographic scales in a tropical area of Asiatic citrus canker endemicity. Evol. Appl. 12:1-16.

R Core Team. 2013. R: A Language and Environment for Statistical Computing. R Foundation for Statistical Computing, Vienna, Austria.

Rademaker, J. L. W., Norman, D. J., Forster, R. L., Louws, F. J., Schultz, M. H., and de Bruijn, F. J. 2006. Classification and identification of Xanthomonas translucens isolates, including those pathogenic to ornamental asparagus. Phytopathology 96:876-884.

Raja, N. I., Rashid, H., Khan, M. H., Chaudhry, Z., Shah, M., and Bano, A. 2010. Screening of local wheat varieties against bacterial leaf streak caused by different strains. Pak. J. Bot. 42:1601-1612.

Rambaut, A., Drummond, A. J., Xie, D., Baele, G., and Suchard, M. A. 2018. Posterior summarization in Bayesian phylogenetics using tracer 1.7. Syst. Biol. 67:901-904

Reddy, C. S., Godkin, J., and Johnson, A. G. 1924. Bacterial blight of rye. J. Agric. Res. 28:1039-1040.

Rozas, J., Sánchez-DelBarrio, J. C., Messeguer, X., and Rozas, R. 2003. DnaSP, DNA polymorphism analyses by the coalescent and other methods. Bioinformatics 19:2496-2497.

Sands, O. C., Mizrak, G., Hall, V. N., Kim, H. K., Bockelman, H. E., and Golden, M. J. 1986. Seed transmitted bacterial diseases of cereals: Epidemiology and control. Arab J. Plant Prot. 4:125-127.

Sapkota, S., Zhang, Q., Chittem, K., Mergoum, M., Xu, S. S., and Liu, Z. 2018. Evaluation of triticale accessions for resistance to wheat bacterial leaf streak caused by Xanthomonas translucens pv. undulosa. Plant Pathol. 67:595-602.

Sen, Y., Aysan, Y., Mirik, M., Ozdemir, D., Meijer-Dekens, F., van der Wolf, J. M., Visser, R. G. F., and van Heusden, S. 2018. Genetic characterization of Clavibacter michiganensis subsp. michiganensis population in Turkey. Plant Dis. 102:300-308.

Smith, E. F., Jones, L. R., and Reddy, C. S. 1919. The black chaff of wheat. Science 50:48.

Smith, K., Schiefelbein, E., Wiersma, J., Dill-Macky, R., Smith, M., and Steffenson, B. 2014. 2014 Barley Field Crop Trials Results. Minnesota Agricultural Experiment Station.

Tillman, B. L., and Harrison, S. A. 1996. Heritability of resistance to bacterial streak in winter wheat. Crop Sci. 36:412-418.

Tillman, B. L., Harrison, S. A., Clark, C. A., Milus, E. A., and Russin, J. S. 1996. Evaluation of bread wheat germplasm for resistance to bacterial streak. Crop Sci. 36:1063-1068

Tillman, B. L., Kursell, W. S., Harrison, S. A., and Russin, J. S. 1999. Yield loss caused by bacterial streak in winter wheat. Plant Dis. 83:609-614.

Vauterin, L., Hoste, B., Kersters, K., and Swings, J. 1995. Reclassification of Xanthomonas. Int. J. Syst. Bacteriol. 45:472-489.

Waney, V. R., Kingsley, M. T., and Gabriel, D. W. 1991. Xanthomonas campestris pv. translucens genes determining host-specific virulence and general virulence on cereals identified by Tn5-gusA insertion mutagenesis. Mol. Plant-Microbe Interact. 4:623-627.

Wen, A., Jayawardana, M., Fiedler, J., Sapkota, S., Shi, G., Peng, Z., Liu, S., White, F. F., Bogdanove, A. J., Li, X., and Liu, Z. 2018. Genetic mapping of a major gene in triticale conferring resistance to bacterial leaf streak. Theor. Appl. Genet. 131:649-658.

Wichmann, F., Müller Hug, B., Widmer, F., Boller, B., Studer, B., and Kölliker, R. 2011. Phenotypic and molecular genetic characterization indicate no major race-specific interactions between Xanthomonas translucens pv. graminis and Lolium multiflorum. Plant Pathol. 60:314-324.

Young, J. M., Park, D. C., Shearman, H. M., and Fargier, E. 2008. A multilocus sequence analysis of the genus Xanthomonas. Syst. Appl. Microbiol. 31:366-377.

Zacaroni, A. B., Koike, S. T., de Souza, R. M., and Bull, C. T. 2012. Bacterial leaf spot of radicchio (Cichorium intybus) is caused by Xanthomonas hortorum. Plant Dis. 96:1820. 